\title{
TAREKAT QADARIYAH WA NAQSABANDIYAH: IMPLIKASINYA TERHADAP KESALEHAN SOSIAL
}

\author{
Firdaus \\ Universitas Islam Negeri RadenIntan Lampung \\ firdaus@radenintan.ac.id
}

\begin{abstract}
The Qoodiriyah Naqshbandiyah Tariqa is a combination of two large tariqas, the Tariqah Qadiriyah and the Naqshbandiyah Tariqa. The founder of this new tarekat was a great Sufi Sheikh who was then the Imam of the Al-Haram Mosque in Makkah al-Mukarramah, Shaykh Ahmad Khatib Ibn Abd. Ghaffar al-Sambasi al-Jawi (w.1878 AD). He is a great scholar of the archipelago who lived until the end of his life in Mecca. Shaykh Ahmad Khatib is a murshid of Tariqah Qadiriyah. Social piety is one of the important joints in Islam. Social piety is an application of one's muamalah which is a barometer of one's ritual piety level. The Qadiriyah Naqsabandiyah (TQN) Congregation is a religious social institution that also has a stake in realizing a minimum social piety program for its group. In this case, TQN synergizes both ritual and social piety to achieve the desirable khairu ummah.
\end{abstract}

\section{Abstrak}

Tarekat Qoodiriyah Naqsyabandiyah adalah perpaduan dari dua buab tharekat besar, yaitu Thariqah Qadiriyah dan Thariqah Naqsabandiyah. Pendiri tarekat baru ini adalah seorang Syekh Sufi besar yang saat itu menjadi Imam Masjid AlHaram di Makekah al-Mukarramah, Syaikh Ahmad Khatib Ibn Abd.Ghaffar al-Sambasi al-Jawi (w.1878 M.). Dia adalah ulama besar nusantara yang tinggal sampai akhir hayatnya di Makkah. Syaikh Abmad Khatib adalah mursyid Thariqah Qadiriyah. Kesalehan Sosial merupakan salah satu sendi penting dalam Islam. Kesalehan sosial merupakan aplikasi dari muamalah seseorang yang menjadi salah satu barometer bagi tingkat Kesalehan ritual seseorang. Tarekat Qadiriyah Naqsabandiyah (TQN) merupakan lembaga 
Sosial keagamaan yang juga mempunyai andil dalam mewnjudkan program kesalehan social minimal bagi kelompoknya. Dalam hal ini TQN bersinergi melakukan kedua kesalehan baik ritual maupun social demi mencapai khairu ummah yang diidamkan.

Keywords: Tariqa, Qadiriyah wa Naqsabandiyah, Diversity, Social, Sufism

\section{A. Pendahuluan}

Problematika utama yang dihadapi oleh masyarakat didalam kehidupan sehari-hari adalah masalah tanggung jawab untuk mengimplementasikan nilai-nilai sosial keagamaan itu sendiri. Dalam hal ini tarekat merupakan salah satu jalan ajaran agama islam yang menuntun umatnya dalam mendekatkan diri kepada Allah SWT yang didalamnya ada nilai-nilai sosial keagamaan.

Tarekat yang berarti jalan, petunjuk dalam melakukan sesuatu ibadat sesuai dengan ajaran yang ditentukan dan dicontohkan oleh Nabi dan dikerjakan oleh sahabat dan tabi'in, turun-temurun sampai kepada guru-guru, sambung-menyambung dan rantai-berantai. Guruguru yang memberikan petunjuk dan pimpinan ini dinamakan mursyid yang mengajar dan memimpin muridnya sesudah mendapat ijazah dari gurunya pula sebagaimana tersebut dalam silsilahnya. ${ }^{1}$

Nabi Muhammad SAW. adalah Nabi terakhir yang diutus oleh Allah SWT dengan membawa wahyu sebagai pedoman umat manusia. Oleh sebab itu kita sebagai umat islam harus beriman (meyakini) Nabi Muhammad adalah Rasul Allah dan mewarisi segala apa yang diajarkannya. Seperti firman Allah surat Al-Fath ayat 9:

Artinya: Supaya kamu sekalian beriman kepada Allab dan Rasul-Nya, menguatkan (agama)Nya, membesarkan-Nya. dan bertasbih kepadaNya di waktu pagi dan petang. ${ }^{2}$

Umat islam tentu mempunyai tujuan yang sangat penting salah satunya adalah untuk mendekatkan diri kepada Allah SWT.

1 Abubakar Aceh, Pengantar Ilmu Tarekat, (Solo: Penerbit dilindungi undang-undang. 1996), h. 67

2 Depag RI, Al-qur'an dan Terjemah, (Bandung: Diponegoro, 2012), h. 210 
Dalam mendekatkan diri kepada Allah tidak cukup hanya melaksanakan kewajiban-kewajiban yang diberikan kepada umat islam. Karena Nabi Muhammad yang sudah suci hatinya, kuat imannya dan dijamin masuk surga oleh Allah SWT, beliau masih juga melaksanakan ibadah-ibadah sunnah sebagai pelengkap ibadah wajib. Muslim awam dalam mengikuti amalan-amalan yang dicontohkan oleh Nabi, membutuhkan seseorang yang memimpin dan membimbing yang disebut syeikh(mursyid) atau guru.

Syekh (mursyid) atau guru mempunyai kedudukan yang penting dalam tarekat. Ia tidak saja merupakan seorang pemimpin yang mengawasi murid-muridnya dalam kehidupan lahir dan pergaulan sehari-hari, supaya tidak menyimpang dari ajaran-ajaran islam dan terjerumus dalam ma'siat, berbuat dosa besar maupun dosa kecil, yang segera harus ditegurnya, tetapi ia merupakan pemimpin kerohanian yang tinggi sekali dalam kedudukan tarekat itu. Ia merupakan perantaraan dalam ibadat antara murid dan Tuhan. Syekh ialah orang yang sudah mencapai maqam rijalul kamal, seorang yang sudah sempurna suluknya dalam ilmu syari'at dan hakikat menurut Al-Qur'an, sunnah dan ijma'. ${ }^{3}$

Tarekat qodiriyah merupakan satu diantara macam-macam ajaran tarekat dalam agama islam. Tarekat ini didirikan oleh syekh Abdul Qadir Al-Jailani, beliau seorang alim dan zahid. Pada mulanya beliau seorang ahli fiqh yang terkenal dalam madzhab Hambali, kemudian sesudah beralih kegemarannya kepada ilmu tarekat dan hakekat menunjukkan keramat dan tanda-tanda yang berlainan dengan kebiasaan sehari-hari. ${ }^{4}$

Inti dalam ajaran tarekat adalah mendekatkan diri kepada Allah SWT., yang didalamnya termasuk berdzikir. Seperti firman Allah surat Al-Ahzab ayat 41-42 yang artinya: 1996), h. 97

${ }^{3}$ Amin, Najmudin al-Kurdi, Tanwirul Qulub, Juz Ii, (Beirut : Dar al-Fikr, ${ }^{4}$ Abu Bakar, Pengantar Ilmu Tarekat ..., h. 145. 
Artinya: Hai orang-orang yang beriman, berzdikirlah (dengan menyebut nama) Allah, rikir yang sebanyak-banyaknya. 42. Dan bertasbiblah kepadaNya diwaktu pagi dan petang. ${ }^{5}$

Masyarakat yang sudah mengikuti ajaran tarekat diharapkan sudah menerapkan nilai-nilai sosial keagamaannya dengan baik. Karena di dunia ini banyak berbagai macam keturunan, lingkungan dan berbagai jenis karakter. Sehingga dalam menjalankan dan menerapkan nilai-nilai sosial keagamaannya tentu banyak tantangannya. Banyak penganut tarekat Qodiriyah yang merasa dirinya sudah menjalankan ajaran Rasulullah dengan baik, tapi dalam menerapkan social keagamaannya dalam kehidupan sehari-hari masih kurang. Ketika mau berangkat ke pengajian, penuh dengan semangat dan ceria. Namun di pengajian masih ada juga yang membicarakan teman jama'ah lain.

\section{B. Konsep Ajaran Tarekat Qodiriyah wa Naqsabandiyah}

Pemuka sekaligus pendiri tarekat ini adalah Sayyid Muhammad Muhyiddin 'Abdul-Qodir Jilani, yang wafat pada tahun 1266 M di usia sembilan puluh tahun. (Valiuddin, 1997: 121). Tarekat Qadiriyah tidak dinamai oleh Syeikh Abdul Qadir Jailani, namun oleh murid sekaligus mursyid di bawahnya yaitu Syeikh Abdul Aziz.Tarekat ini dikenal dengan metode dzikir yang disebut dzikir jahar (diucapkan dengan suara keras). Tarekat Naqsabandiyah didirikan oleh Muhammad bin Bahauddin al-Uwaisi al-Bukhari (717791/1318-1389) dari Bukhara (dulu bagian dari Uni Sovyet). Naqsabandi berasal dari kata "Naksyaband" yang berarti lukisan, atau penjagaan bentuk kebahagiaan hati. Tarekat ini diberi nama Naqsabandiyah karena Syeikh Bahauddin dalam memberikan lukisan kehidupan gaib. ${ }^{6}$

Syeikh Bahauddin belajar tarekat dan ilmu adab pada Amir Sayyid Kulal al-Bukhari (w. 772/1371), namun dalam segi kerohanian, beliau belajar pada Abd al-Khaliq al-Ghujdawani (w. 617/1220)68. Beliau juga pernah belajar tasawuf kepada Muhammad

${ }^{5}$ Depag RI, Alqur'an dan Terjemah..., h, 179

6 Sri Mulyati, dkk., Mengenal dan Memahami Tarekat-tarekat Muktabarah di Indonesia, (Jakarta: Prenada Media, 2005), h. 256 
Baba al-Sammasi (w. 740/1340) di al-Sammas, Bukhara, pada usia delapan belas tahun. Orang yang dianggap sebagai pendiri pertama tarekat Naqsabandiyah adalah Abdul. Khaliq al-Ghujdawani. Beliau bersama Khwajagan (para tuan guru) tinggal di Asia Tengah dan mengajarkan dzikir khafi (zikir dalam hati) kepada Syeikh Bahauddin sebagai dzikir khas Tarekat Naqsyabandiyah.

Syeikh Ahmad Khatib tidak serta merta menggabungkan ajaran dua tarekat besar di atas. Beliau menganggap bahwa kedua tarekat tersebut memiliki kesamaan pandangan mengenai tasawuf yang tidak mengesampingkan syariat serta menentang faham wihdah al-Wujud, sehingga jenis dan metode dzikirnya dapat saling melengkapi. Tarekat Qadiriyah mengajarkan dzikir Jahr Nafi Itsbat, sedangkan Tarekat Naqsabandiyah mengajarkan dzikir Sirri Ism Dzat. Penggabungan ini juga membuat metode murakkabah menjadi lebih efektif dan efisien sehingga diharapkan para muridnya dapat mencapai derajat kesufian yang lebih tinggi.

Dalam bukunya Abu Bakar Aceh ${ }^{7}$ menjelaskan bahwa "Syeikh Abdul Qadir Jailani adalah seorang alim dan zahid, dianggap qutubul'aqtab, mula pertama seorang ahli fiqh yang terkenal dalam madzhab hambali, kemudian sesudah beralih kegemarannya kepada ilmu tarekat dan hakekat menunjukkan keramat dan tandatanda yang berlainan dengan kebiasaan sehari-hari". Orang dapat membaca sejarah hidup dan keanehan-keanehannya dalam kitab yang dinamakan Manaqib Syeikh Abdul Qadir Jailani, asli tertulis dalam bahasa Arab, dan terjemahannya dalam bahasa Indonesia tersiar luas di Negeri kita, yang dibaca oleh rakyat pada waktu-waktu tertentu, konon untuk mendapatkan berkahnya.

Sajak dalam masa hidupnya sudah ada beberapa orang yang telah menyempurnakan ajarannya dan pergi menyiarkan ajaran itu ke tempat lain. Seorang dari padanya ialah Ali bin Al-Hadda, yang kemudian terkenal di Yaman dengan gerakannya, yang lain bernama Muhammad Batha' ini bertempat tinggal di Baalbek, tetapi memperkembangkan juga tarekat ini di Syria. Taqiyuddin Muhammad Al-Yunani terkenal sebagai seorang penyair tarekat Qodiriyah yang

\footnotetext{
7 Abu Bakar, Pengantar Ilmu Tarekat ..., h.138-310
} 
ternama di Baalbek, sedang Muhammad bin Abdus Samad adalah seorang yang dianggap keramat di Mesir, karena katanya ia mewakili Abdul Qadir sendiri, yang akan menuntun manusia menempuh jalan menuju Tuhan dan Rasul-Nya. ${ }^{8}$

Kaum sufi dalam tarekat Qodiriyah menitikberatkan pengosongan "sirr" dari segala jenis pikiran selain Allah dan penyucian jiwa dari segala macam sifat tercela, hewani, dan syaithani. Mereka berpandangan bahwa ruh manusia berasal dari "Alam Perintah" (alam al-amr) dan mampu memantulkan cahaya Ilahi. Namun, karena berbagai kotoran yang ada dalam jiwa, ia tidak bisa berbuat demikian. (Valiuddin, 1997: 38).

Dalam tarekat ini, dzikr dilakukan dengan keras (yakni, bersuara) tetapi tidak terlalu keras sehingga bertentangan dengan hadis yang diriwayatkan oleh Abu Musa Asy'ari: Wahai manusia! Janganlah kalian menyusahkan diri dengan suara keras (maksudnya, ucapkanlah dengan perlahan). Kalian tidak sedang menyeru Tuhan yang buta dan tuli. Kalian menyeru Tuhan yang mendengar kalian, melihat kalian dan yang bersama kalian. Tuhan yang kalian seru jauh lebih dekat kepadamu dari leher untamu. Dzikr utama dalam tarekat ini adalah lailaha illallah. Cara melakukannya ialah sebagai berikut: sang dzakir (seseorang yang melantunkan dzikr) mesti duduk seperti shalat sambil menghadap kiblat (qiblah) dan harus menutup matanya. Ia mesti mengucapkan kata la sembari menarik bunyi seperti dari pusar, mengangkatnya ke bahunya dan kemudian mengucapkan ilaha sembari menarik bunyi itu dari otaknya. Sesudah itu, ia mestilah mengetukkannya, yakni mencamkan kata-kata illa Allah dengan kuat pada hatinya, seraya memikirkan bahwa hanya Allah sajalah Wujud hakiki dan Tujuan hakiki dalam kehidupan. Ia mesti menandaskan atau mengarahkan semuanya ini kepada Zat Suci Allah semata. Sang hamba yang baru mulai mamasuki tarekat bakal menafikan dan menegaskan kecintaan; sang hamba yang tengah memasuki tahap menengah akan menafikan bahwa hanya Allah sajalah tujuan dalam kehidupan; dan sang arif akan menafikan dan menegaskan eksistensi. Penafian dan penegasan ini dimaksudkan untuk menyesuaikan

${ }^{8}$ Kiki Muhamad Hakiki, Debus Banten: Pergeseran Otentisitas dan Negosiasi Islam-Budaya Lokal, Kalam: Jurnal Studi Agama dan Pemikiran Islam, Volume 7, Nomor 1, Juni 2013, h. 5. 
keadaan mental seseorang yang mengingat Allah. Inilah tahap pertama dalam membersihkan hati. ${ }^{9}$

Pokok-pokok tarekat qodiriyah itu ada lima, diantaranya: Tinggi cita-cita, menjaga segala yang haram, memperbaiki khidmat terhadap Tuhan, melaksanakan tujuan yang baik, memperbesarkan arti karunia nikmat Tuhan. (Abu Bakar, 1996: 73). Menurut tarekat qodiriyah siapa yang tinggi cita-citanya naiklah martabatnya, siapa yang menjaga segala yang haram maka Allah memelihara kehormatannya, siapa yang memperbaiki khidmat terhadap Tuhan kekallah ia dalam petunjuk, siapa yang memperbesar Allah (karena nikmat- Nya) ia akan mendapatkan tambahan nikmat dari-Nya.

\section{Bentuk-bentuk Perilaku Dari Kesalehan Sosial}

Bentuk-bentuk perilaku yang berdasarkan nilai-nilai social keagamaan adalah sebagai berikut:

1. Amanah/jujur

Jujur artinya sesuainya sesuatu dengan kenyataannya yang sesungguhnya, dan ini tidak saja berupa perkataan tetapi juga perbuatan. Dalam bahasa arab, jujur disebut sidiq (As-Shidqu), lawan dari kizib (Al-kizbu) yaitu bohong atau dusta. Orang yang jujur adalah orang yang berkata, berpenampilan dan bertindak apa adanya, tanpa dibuat-buat. Kejujuran adalah sikap yang jauh dari kepalsuan atau kepura-puraan. Sedangkan sikap jujur adalah suara hati nurani terdalam manusia, karenanya ia senantiasa menempati posisi terhormat dihadapan siapa pun. ${ }^{10}$

2. Tolong menolong

Tolong menolong adalah termasuk persoalan-persoalan yang penting dilaksanakan oleh seluruh umat manusia secara bergantian, sebab tidak mungkin seorang manusia itu akan dapat hidup sendiri-sendiri tanpa menggunakan cara pertukaran kepentingan dan kemanfaatan. Antara seorang dengan yang lain

9 Mir Valaudin, Zikir dan Kontemplasi dalam Tasawuf. (Bandung: Hidayah Press. 1997), h.121-122

${ }^{10}$ Wahid Ahmadi, Risalah Akblak. (Solo: Era Intermedia. 2004). h. 41 - 
tentu saling hajat-menghajatkan, butuh-membutuhkan dan tolong menolong.

3. Sedekah

Dijelaskan dalam terjemahan Durratun Nasihin (50) tentang keutamaan memberi sedekah:QS. Al-Baqoroh: 261

Artinya 261. Perumpamaan (nafkah yang dikeluarkan oleh) orang-orang yang menafkabkan hartanya di jalan Allah adalah serupa dengan sebutir benih yang menumbubkan tujuh bulir, pada tiap-tiap bulir seratus biji. Allah melipat gandakan (ganjaran) bagi siapa yang Dia kehendaki. dan Allab Maba Luas (karunia-Nya) lagi Maha mengetabui.

4. Ukhuwah Islamiyah

Secara bahasa ukhuwah yang diartikan "persaudaraan", terambil dari kata yang pada mulanya berarti "memperhatikan". Makna asal ini memberi kesan bahwa persaudaraan mengharuskan adanya perhatian semua pihak yang merasa bersaudara. Ukhuwah islamiyah, artinya ialah persaudaraan islam, yaitu persaudaraan yang diajarkan oleh islam yang berlaku di kalangan sesama orang islam. Sesungguhnya ajaran persaudaraan islam, sudah terkandung di dalam kata yang menjadi nama bagi agama kita itu sendiri, yaitu "Islam", sebab salah satu diantara makna "Islam": damai. Yaitu damai dengan sesame manusia, tentu saja lebih-lebih damai dengan sasama manusia yang beragama islam itu sendiri. Rosulullah SAW merumuskan pengertian demikian ini dengan sabdanya:"Orang islam itu ialah orang, yang orang-orang islam lainnya selamat dari gangguan tangan dan lesannya”. (Riwayat Bukhori).

Maksudnya bahwa yang disebut orang islam itu ialah orang yang segala tingkah lakunya baik yang berupa perbuatan maupun perkataan tidak mengganggu orang islam lainnya, sehingga orang islam yang lain itu merasa aman dari segala tingkah lakunya itu. ${ }^{11}$

5. Iffah

Iffah artinya menghindarkan diri dari sesuatu yang haram dan syubhat. Sikap itu akan memperkokoh keberagamaan seseorang

${ }^{11}$ Humaidi Tatapangarsa, Akblaq yang Mulia. (Surabaya: PT Bina Ilmu Offset, 1991), h. 125-126. 
dan merupakan kebiasaan ulama-ulama yang mengamalkan ilmunya. Sesungguhnya sesuatu yang haram itu terbagi menjadi dua kelompok: pertama, sesuatu yang diharamkan karena bendanyaitu sendiri, seperti jenazah, darah, arak dan lainnya. Kelompok ini diharamkan untuk dikomsumsi secara mutlak, kecuali bila terpaksa yakni untuk mempertahankan kelangsungan hidup.

Kedua, bendanya halal, seperti gandum dan air suci, tetapi benda itu milik orang lain. Dengan demikian benda itu haram digunakan sebelum memilikinya berdasarkan prosedur syara', misalnya dengan cara membelinya, menerima hibah, atau menerima warisan.

Sesuatu yang syubhat pun terdiri atas berbagai tingkatan: pertama, yang diyakini keharamannya dan diragukan kehalalannya. Syubhat seperti ini hukumnya haram. Kedua, yang diyakini kehalalannya dan diragukan keharamannya. Meninggalkan syubhat seperti ini merupakan tindakan yang baik. Ketiga, kemungkinan haram dan kemungkinan halalnya sama.

\section{Implementasi Nilai-Nilai Sosial Keagamaan Penganut Tarekat Qodiriyah}

Nilai-nilai sosial keagamaan adalah hal-hal yang dianggap baik, bermanfaat, dan bermutu dalam hubungan dengan sesama masyarakat yang dijiwai atau diarahkan oleh ajaran agama. Jadi implementasi nilai-nilai social keagamaan penganut Tarekat qodiriyah pada jama'ah pengajian adalah suatu penerapan hal-hal yang dianggap baik, bermanfaat, dan bermutu dalam hubungan dengan sesama masyarakat yang dijiwai atau diarahkan oleh ajaran agama. Dengan ilmu dan berbagai pengalaman yang didapat, kemudian mereka berusaha menerapkan dalam kehidupan sehari-hari baik amalan ibadah kepada Allah SWT maupun amalan kepada sesame masyarakat.

Para Jama'ah yang sudah dibai'at, berarti siap untuk menjalankan amalan-amalan (ilmu) yang telah mereka dapatkan. Dalam menjalankan amalan-amalan tarekat Qodiriyah itu memang 
mudah namun dalam beristiqomah dalam menjalankannya itu yang tidak mudah apalagi menerapkan dalam kehidupan sehari-hari. Namun jama'ah tarekat ini sudah berusaha menjalankan amalanamalan itu dengan baik dan begitu pula dengan nilai-nilai sosial keagamaannya. Walau itu masih jauh dari sempurna. Ajaran tarekat Qodiriyah inilah yang kemudian menjadikan jama'ah tarekat bisa membedakan sifat nafsu yang baik dan sifat nafsu yang tercela. Jadi di dalam ajaran tarekat Qodiriyah itu terdapat nilai-nilai sosial keagamaan yang wajib di laksanakan oleh jama'ah tarekat. Sehingga antara ibadah kepada Allah SWT dan penerapan nilai-nilai sosial keagamaannya dapat seimbang.

\section{E. Hubungan Tarekat dengan Kesalehan Sosial}

Setiap ibadah, baik mahdhah maupun ghair mahdhah seharusnya pasti berimplikasi sosial bagi para pelakunya. Implikasi sosial tersebut dapat dilihat dari beberapa ayat dalam Al-Quran. Misalnya dalam ibadah shalat, maka Al-Quran menggariskan bahwa shalat dapat mencegah keji dan munkar, maka dapat disimpukan bahwa ketika ada seseorang yang terlihat sangat rajin shalat namun tidak berhasil mewujudkan implikasi sosial shalat berupa pencegahan terhadap hal-hal yang keji dan munkar, kemungkinan besar ada sesuatu yang salah dalam shalatnya. Contoh lain misalnya menunaikan ibadah haji yang mempunyai implikasi sosial dengan gelar haji mabrur, dalam arti orang yang telah berhaji seharusnya akan menimbulkan perubahan yang signifikan dalam intensitas ritual maupun perbaikan interaksi sosial dengan masyarakat. Apabila ternyata yang terjadi malah sebaliknya, yaitu orang yang haji tersebut malah cenderung sombong dengan gelar hajinya, dan interaksi dengan masyarakat terganggu, maka kemungkinan ada yang salah dalam hajinya.

Ibadah-ibadah yang langsung berhubungan dengan ekonomi seperti zakat, infak, shadaqah, wakaf, warisan, atau hadiah tentu mempunyai implikasi sosial yang langsung terlihat membantu sesama dengan cara meningkatkan potensi harta bagi yang diberi.

Puasa juga mempunyai implikasi sosial yang sangat kental. Batasanbatasan yang diberlakukan bagi orang yang berpuasa seperti pengurangan sampai penghilangan pahala puasa apabila orang yang 
berpuasa melanggar beberapa perilaku seperti membicarakan orang lain,marah, atau berbohong menjadikan orang-orang yang berpuasa lebih menghargai orang lain.

Sama halnya dengan ibadah-ibadah di atas, tarekat yang merupakan jalan alternatif bagi sebagian orang untuk beribadah dengan khas masing-masing yang tentunya lebih dominan berbentuk dzikir dalam rangka taqarrub kepada Allah SWT juga mempunyai implikasi sosial.

Ada dua hal yang perlu dilihat dalam mencari hubungan antara tarekat dengan Kesalehan Sosial. Pertama, tarekat yang dipandang dari segi ritualnya. Kedua, tarekat dipandang sebagai tasawuf yang melembaga atau tarekat dipandang dari segi organisasi.

Pandangan pertama mengenai tarekat yang dipandang dari segi ritualnya dalam hal ini berbentuk dzikir mempunyai gambaran jelas yang telah digariskan Al-Quran.

\section{F. Konsep Peningkatan Kesalehan Sosial}

Istilah "Kesalehan Sosial" berasal dari dua kata yaitu "kesalehan" dan "sosial". Sebelum mendapatkan awalan dan akhiran, kata "kesalehan" berasal dari kata dasar "saleh" atau "shaleh". Kata "shaleh" berasal dari bahasa Arab yaitu "shaluha" yang apabila diartikan merupakan kebalikan dari kata "fasad". ${ }^{2}$ Apabila "fasad" dapat dikatakan sebagai "membuat kerusakan", maka "sholuha" dapat diartikan sebagai "membuat kebaikan". Setelah ditambah dengan awalan "ke" dan akhiran "an", kata "shaleh" berubah menjadi "kesalehan" yang diartikan sebagai kesungguhan hati dalam hal menunaikan agama atau dapat diartikan juga kebaikan hidup. ${ }^{13}$

Louis Ma'luf dalam kamus Munjid mengatakan bahwa setidaknya terdapat beberapa kemungkinan kondisi yang dapat menggunakan kata "shaleh" ditinjau dari segi bahasa, yaitu :

1. Telah baik keadaan

12 Louis Ma'luf, Munjid. (Jojakarta: PT Mutiara, 1977), Cet.ke-22, h.432

13 W.J.S Poerwadarminta, Kamus Umum Bahasa Indonesia (Jakarta: Balai Pustaka,1993), h. 856 
2. Aktifitas yang menjadikan baik (majas)

3. Membiasakan kebaikan (jika dihubungkan dengan perbuatan)

4. Berbuat baik kepada objek

5. Kondisi yang menjadikan baik

6. Mendamaikan (islah). ${ }^{14}$

Adapun kata "sosial" berasal dari kata Latin "socius" yang berarti kawan atau teman. Sosial dapat diartikan sebagai bentuk perkawanan atau pertemanan yang berada dalam skala besar yaitu masyarakat. Berarti social adalah segala sesuatu yang berhubungan dengan masyarakat atau kemasyarakatan. ${ }^{15}$ Yang lebih penting adalah bahwa kata social mengandung pemahaman adanya sifat berjiwa pertemanan, terbuka untuk orang lain dan tidak bersifat individual atau egoistik atau tertutup terhadap orang lain. Kata kesalehan dan sosial memiliki arti yang lebih luas. Beberapa ahli telah mencoba mendefinisikan arti dari Kesalehan Sosial ini antara lain :

a. Mustafa Bisri

"Kesalehan Sosial" adalah perilaku orang-orang yang sangat peduli dengan nilai-nilai Islami, yang bersifat sosial. Suka memikirkan dan santun kepada orang lain, suka menolong, dan seterusnya; meskipun orang-orang ini tidak setekun kelompok kesalehan ritual dalam melakukan ibadat seperti sembayang dan sebagainya itu. Lebih mementingkan hablun minan naas." 16

b. Abdurrahman Wahid (Gus Dur)

"Kesalehan Sosial adalah suatu bentuk kesalehan yang tak Cuma ditandai oleh rukuk dan sujud, melainkan juga oleh cucuran keringat dalam praksis hidup keseharian kita. “17

c. Prof. Dr. HM. Djawad Dahlan

"Kesalehan Sosial adalah mutu atau kualitas kebaikan individu yang berpangkal pada berbagai istilah, seperti manusia kaffah, khalifah filardli, muttaqin, shalihin, mu'minin, syakirin, dan muflihin." 18

${ }^{14}$ Ma'luf, Munjid..., h. 432

15 Poerwadarminta, Kamus Umum Bahasa Indonesia..., h. 961

${ }^{16}$ Mustafa Bisri, Menimbang Arti Kesalehan Sosial, dari http://www.kesalehansosial. blogspot.com/

17 Muhammad Sobary, Kesalehan Sosial, Kesalehan Ritual, dari http://www.kesalehansosial. blogspot.com

18 Djawad Dahlan, dkk., Kumpulan Makalah Nilai dan Aplikasi Kesalehan Sosial dalam Kehidupan Bermasyarakat (Pemerintah Provinsi Jawa Barat, 2005), h. 2 
d. Prof. Dr. H. Dadang Kahmad, MS.

"Kesalehan Sosial adalah aktualisasi atau perwujudan iman dalam praksis kehidupan sosial." 19

Keberadaan Tarekat Qadiriyah Naqsabandiyah diharapkan menjadikan Kesalehan Sosial mengalami "peningkatan". Kata "peningkatan" berasal dari kata dasar "tingkat" dan mendapatkan awalan "pe" dan akhiran "an". Kata "peningkatan" dapat diartikan dalam beberapa kondisi yaitu :

a) Menginjak, menaiki atau memanjat

b) Naik dalam berbagai hal seperti meninggi, membumbung, dan menaik

c) Beralih kepada peristiwa atau masa

d) Menjadi bertambah banyak. ${ }^{20}$

Peningkatan Kesalehan Sosial adalah penambahan kualitas maupun kuantitas kesalehan seseorang secara sosial melalui interaksi terencana maupun insidental yang akan menimbulkan dampak sosial bagi subjek pelaksana kegiatan Kesalehan Sosial maupun objek kegiatan Kesalehan Sosial.

\section{G. Wilayah Kesalehan Sosial}

Kata kesalehan setelah digabung dengan sosial tentunyamempunyai wilayah yang sangat luas karena semua aspek yang berkembang dalam masyarakat dapat menjadi bagian dari masalah sosial.

Namun secara garis besar wilayah Kesalehan Sosial sejalan dengan perbaikan (islah) yang diupayakan melalui Al-Quran. Menurut Prof. Dr. Muhammad Abdul Azhim, seorang ahli ilmu Al-Quran dan Sunnah, upaya islah yang dilakukan Al-Quran yang sejalan dengan wilayah Kesalahen Sosial dapat dinilai dari beberapa segi antara lain :

a. Kesalehan Sosial dalam Pemantapan Akidah (islahul 'aqoid) ${ }^{21}$

\footnotetext{
19 Ibid

20 Poerwadarminta, Kamus Umum Bahasa Indonesia..., h. 1077-1078

${ }^{21}$ Djawad Dahlan, dkk., Nilai dan Aplikasi Kesalehan Sosial dalam Kehidupan Bermasyarakat, (Pemerintah Provinsi Jawa Barat, 2005), h. 2
} 
Al-Quran seringkali menyandingkan kata iman dan amal shaleh dalam satu kalimat. Hal itu menunjukkan betapa kedua hal tersebut baik Kesalehan Ritual (ritual piety) dan Kesalehan Sosial (social piety) menjadi satu kesatuan yang tidak dapat dipisahkan. Berbicara mengenai Kesalehan Ritual dalam hal ini "iman" harus berimplikasi amal shaleh. Begitu juga sebaliknya, untuk mengaplikasikan Kesalehan Sosial dalam hal ini "amal shaleh" harus dilandasi oleh akidah yang kokoh sehingga perjalanan dunia akhirat menjadi seimbang dan responsible.

b. Kesalehan Sosial dalam Pemantapan Ibadah (islahul 'ibadah) ${ }^{22}$

Banyak barometer yang dapat digunakan dalam Islam. Salah satunya adalah kesalehan seseorang atau kelompok dapat dilihat dari shalatnya. Apabila shalatnya berhasil memenuhi patokanpatokan yang telah ditetapkan seperti pengaturan shaff, pemilihan imam, maupun aplikasi ritual shalatnya, maka dapat dipastikan orang atau kelompok tersebut merupakan orang atau kelompok yang juga shaleh secara sosial. Sebaliknya jika orang atau kelompok tersebut mengalami hambatan dalam kehidupan sosial, bisa jadi salah satu penyebabnya adalah terdapatnya kesalahan dalam shalatnya. Untuk itulah Kesalehan Sosial erat kaitannya dengan pemantapan ibadah. Semakin intensif ibadah seseorang seharusnya dia semakin shaleh secara sosial.

c. Kesalehan Sosial dalam Pemantapan Akhlak (islahul akhlak) ${ }^{23}$

Barometer lain yang dapat digunakan dalam Islam adalah "apabila hari ini lebih baik dari kemarin, maka kita tergolong orang yang beruntung. Apabila hari ini sama dengan hari kemarin maka kita tergolong orang yang rugi. Dan apabila hari ini lebih buruk dari hari kemarin maka kita tergolong orang yang mal'un atau dilaknat oleh Allah SW'T".

Umat Islam secara individu mempunyai potensi untuk melakukan perbaikan dan peningkatan ibadah yang dilakukan setiap harinya. Ibadah itu tidak hanya yang mahdhah, tetapi juga yang ghair mahdhah seperti perbaikan akhlak sebagai misi awal diturunkannya Rasulullah Muhammad SAW. Potensi Kesalehan 
Sosial tentunya berbanding lurus dengan pemantapan akhlak karena secara sosial, keinginan untuk menjadikan hari ini lebih baik dari hari kemarin menjadikan optimalisasi pemantapan akhlak menjadi lebih besar.

d. Kesalehan Sosial dalam Kehidupan Bermasyarakat (islahul ijtima') Al-Quran memberikan banyak seruan untuk kita melakukan Kesalehan Sosial dalam berkehidupan di masyarakat. Berlombalomba dalam kebaikan (fastabaqulkhairaat), tolong menolong dalam kebaikan dan takwa (ta'awun 'ala al-Birri wa at-taqwa), silaturahmi, egality, dan berbagai norma sosial adalah contoh betapa pentingnya kehidupan bermasyarakat sebagai modal untuk melakukan Kesalehan Sosial yang dapat menguntungkan semua pihak dalam masyarakat tersebut.

e. Kesalehan Sosial dalam Pemantapan Politik (islahus siyasah) Wilayah politik tidak dikesampingkan sebagai bagian penting dalam penerapan Kesalehan Sosial. Konsep musyawarah, demokrasi, hak asasi manusia, dan keadilan menjadi kampanye penting bagi penerapan kehidupan politik yang shaleh. Intervensi Kesalehan Sosial dalam daerah politik membuktikan bahwa politik tidak selamanya buruk, tapi dapat ditata sesuai koridor yang telah digambarkan melalui dalil-dalil Al-Quran maupun Sunnah.

f. Kesalehan Sosial dalam Kehidupan Ekonomi (islahul mal)

Islam mengakui adanya hak individu setiap orang dalam mengelola harta. Namun proses mendapatkan dan menggunakan harta perlu mempertimbangkan Kesalehan Sosial dimana dalam harta kita ada hak orang lain yang harus dikeluarkan, baik berupa pengeluaran wajib seperti zakat maupun yang tidak wajib seperti infak, shadaqah, dan wakaf.

Selain itu Kesalehan Sosial juga ditopang dengan menghindari hal-hal tercela seperti riba, korupsi, kolusi, khianat, dzalim, atau tindakan penipuan sebagai motif meraih keuntungan dalam ekonomi.

g. Kesalehan Sosial dalam Kedudukan Wanita (islahun nisa) 
Wanita ditempatkan dalam posisi yang terhormat dalam Islam. Al-Quran juga tidak lupa memberikan konsep mengenai kesetaraan gender, maupun perlindungan hak, martabat, dan kehormatan wanita.

h. Kesalehan Sosial dalam Perdamaian Dunia (islahul jaryi)

Kesalehan Sosial sebagai bagian dari perdamaian dunia dapat dilakukan dengan cara mencintai tanah air, merawat alam semesta, tidak melakukan eksploitasi sumber daya alam dan menghargai perjanjian yang telah dibuat dalam hubungan dengan Negara lain.

\section{H. Indikator-indikator Kesalehan Sosial}

Setelah melihat wilayah Kesalehan Sosial yang dipaparkan oleh Prof. Dr. Muhammad Azhim di atas, dapat diambil benang merah untuk menentukan indikator Kesalehan Sosial. Indikatorindikator ini adalah implementasi kedelapan upaya islah di atas. Secara umum indicator Kesalehan Sosial tercantum dalam Tafsir Ruhul Bayan karya Ismail al-

Buruswi yang minimal berupa :

a. Tidak menyekutukan Allah

b. Bekerja tanpa pamrih

c. Bersih dari sikap riya, ujub dan ingin dipuji

d. Mengikuti jejak langkah dan sunnah Rasulullah SAW

e. Mengajak yang ma'ruf dan mencegah perbuatan munkar

f. Hatinya terbuka untuk menerima kebenaran, lidahnya terjaga, punya perangai baik

g. Memberi manfaat kepada sesama manusia

h. Mementingkan kepentingan orang lain

i. Terbinanya ukhuwah Islamiyah $j$. Terwujudnya kesetiakawanan sosial berupa kasih sayang, ingin menolong dan memberi. ${ }^{24}$

\section{Kegiatan-kegiatan Tarekat Qadiriyah Naqsabandiyah}

Agama tidak hanya dijadikan sebagai kepercayaan untuk menyembah Sang Pencipta. Lebih dari itu, agama dianggap mampu 
menjawab masalah-masalah sosial kemasyarakatan yang tidak jarang membuat masyarakat gamang dalam menentukan arah hidup. Manusia sebagai makhluk sosial tentunya tidak akan menganggap agama sebagai kepercayaan individu. Manusia butuh teman untuk mempercayai agama yang dijadikan media sharing atau sekedar bertanya tentang kepercayaan yang selama ini dianut. Terlepas dari kentalnya doktrin agama untuk mengikat hati para pengikutnya, ternyata agama berpotensi untuk menciptakan komunitas sosial. Komunitas itu bisa terjadi karena satu rasa senasib sepenanggungan, satu daerah, satu pekerjaan, atau satu kiblat.

Syari'ati mengklasifikasikan komunitas sosial ini dalam beberapa term yaitu :

1. Ummah, yaitu sebuah komunitas masyarakat yang hijrah dan saling membantu satu sama lain agar mampu mencapai tujuan yang sama-sama dicita-citakan.

2. Nation, yaitu sebuah komunitas sosial dalam masyarakat yang terbentuk karena ras, kekerabatan, atau kesatuan daerah.

3. Qabilah, yaitu sebuah komunitas sosial masyarakat yang terdiri dari sekumpulan individu yang bersepakat untuk menunjuk satu tujuan atau satu kiblat dalam kehidupan mereka.

4. Qaum, yaitu sebuah komunitas sosial kemasyarakatan yang bertujuan untuk menyelesaikan suatu aktifitas dengan cara berserikat.

5. Sya'b, yaitu sebuah komunitas sosial yang terbentuk sebagai cabang dari satu komunitas lain.

6. Thabaqah, yaitu sebuah komunitas sosial yang mempunyai pola hidup, pekerjaan, dan pendapatan yang nyaris sama bahkan mungkin serupa.

7. Mujtama' atau Jami’ah, yaitu sebuah komunitas sosial yang berkumpul dalam suatu tempat.

8. Thaifah, yaitu sebuah komunitas sosial yang berkumpul dalam satu poros atau zona tertentu.

9. Race atau Ras, yaitu sebuah komunitas sosial yang tergabung karena kesamaan warna kulit, postur, darah, atau ciri-ciri jasmani lainnya 
10. Masse atau Jumhur, yaitu sebuah komunitas sosial yang tersebar pada suatu tempat tertentu

11. People, yaitu suatu komunitas sosial yang menetap menempati suatu kawasan tertentu. ${ }^{25}$

Terbentuknya komunitas sosial seperti disebutkan di atas juga dialami oleh para ikhwan Tarekat Qadiriyah Naqsabandiyah (TQN). Dilandasi dengan pencapaian tujuan yang sama yaitu menentramkan hati dan taqarrub kepada Allah.

\section{J. Kesimpulan}

Tarekat Qadiriyah Naqsabandiyah (TQN) adalah tarekat gabungan antara Tarekat Qadiriyah Naqsabandiyah. Pendirinya adalah Ahmad Khatib Sambas yang mana beliau merupakan pemimpin Tarekat Qadiriyah pada masanya dan seorang syekh dari tarekat Naqsabandiyah. Dari kedua tarekat tersebut Ahmad Khatib Sambas membentuk tarekat baru yang bernama TQN.

Perkembangan dan penyebaran Tarekat Qadiriyah Naqsabandiyah di Indonesia terdapat lima pondok pesantren di Jawa yang sekarang menjadi pusat penyebaran TQN di Indonesia yaitu Pesantren Pegentongan di Bogor (Jawa Barat), Pesantren Suryalaya di Tasikmalaya (Jawbua Barat), Pesantren Mranggen di Semarang (Jawa Tengah), Pesantren Rejoso di Jombang (Jawa Timur), dan Pesantren Tebuireng di Jombang (Jawa Timur).

Ajaran-ajaran dasar tasawuf dari sudut pandang praktik Tarekat Qadiriyyah Naqsabandiyyah diantaranya adalah sikir, talqin dan baiat, latha'if dan amalan TQN lainnya seperti latihan wajib rohani seharihari (dzikrullah sehari-hari), khataman, manakiban, dan khalwah (praktik penyendirian).

25 Nanih Machendrawati dan Agus Ahmad Syafe'i, Pengembangan Masyarakat Islam; Dari Ideology, Strategi, Sampai Tradisi (Bandung: PT Remaja Rosdakarya, 2001), h. 6-7. 


\section{Daftar Pustaka}

Aceh, Abubakar. Pengantar Ilmu Tarekat. Solo: Penerbit dilindungi undang-undang. 1996

Depag RI, Alqur'an dan Terjemah, Bandung: Diponegoro, 2012

Ahmadi, Wahid. Risalah Akblak. Solo: Era Intermedia. 2004

Amin, Najmudin al-Kurdi, Tanwirul qulub, juz II, Beirut : Dar al-Fikr, 1996

Dahlan, Djawad, dkk., Nilai dan Aplikasi Kesalehan Sosial dalam Kehidupan Bermasyarakat. Pemerintah Provinsi Jawa Barat, 2005

Kiki Muhamad Hakiki, Debus Banten: Pergeseran Otentisitas dan Negosiasi Islam-Budaya Lokal, Kalam: Jurnal Studi Agama dan Pemikiran Islam, Volume 7, Nomor 1, Juni 2013.

Ma’luf, Louis, Munjid. Jojakarta: PT Mutiara, 1977

Muhammad Sobary, Kesalehan Sosial, Kesaleban Ritual, dari http://www.kesalehansosial. blogspot.com

Mulyati, Mulyati, Sri, dkk., Mengenal dan Memahami Tarekat-tarekat Muktabarah di Indonesia. Jakarta: Prenada Media, 2005

Mustafa Bisri, Menimbang Arti Kesalehan Sosial, dari http://www.kesalehansosial. blogspot.com

Nanih Machendrawati dan Agus Ahmad Syafe'i, Pengembangan Masyarakat Islam; Dari Ideology, Strategi, Sampai Tradisi, Bandung: PT Remaja Rosdakarya, 2001

Poerwadarminta, W.J.S. Kamus Umum Babasa Indonesia. Jakarta: Balai Pustaka,1993

Tatapangarsa, Humaidi. Akblaq yang Mulia. Surabaya: PT Bina Ilmu Offset, 1991

Valaudin, Mir. Zikir dan Kontemplasi dalam Tasawnf. Bandung: Hidayah Press. 1997 
Firdaus 